Meta

Journal des traducteurs

Translators' Journal

\title{
La traducción literaria en España: pasado, presente y retos para el futuro
}

\section{Susanne M. Cadera}

Volume 60, numéro 2, août 2015

$60^{\mathrm{e}}$ anniversaire. Les horizons de la traduction : retour vers le futur $60^{\text {th }}$ Anniversary. Translation's Horizons: Back to the Future

60mo aniversario. Los horizontes de la traducción: regreso al futuro

URI : https://id.erudit.org/iderudit/1032866ar

DOI : https://doi.org/10.7202/1032866ar

Aller au sommaire du numéro

Éditeur(s)

Les Presses de l’Université de Montréal

ISSN

0026-0452 (imprimé)

1492-1421 (numérique)

Découvrir la revue

Citer ce document

Cadera, S. M. (2015). La traducción literaria en España: pasado, presente y retos para el futuro. Meta, 60(2), 315-315. https://doi.org/10.7202/1032866ar d'utilisation que vous pouvez consulter en ligne. 


\title{
La traducción literaria en España: pasado, presente y retos para el futuro
}

\author{
Susanne M. Cadera \\ Universidad Pontificia Comillas, Madrid, España \\ scadera@comillas.edu
}

El mercado editorial de la traducción de libros en España sigue siendo muy vivo. De hecho, una cuarta parte de los libros editados en España son traducciones. Si comparamos el pasado y el presente de la actividad traductora en España se evidencia una evolución en la forma de traducir. Los estudios universitarios de Traducción e Interpretación que surgieron a comienzos de los años 90 del siglo XX con profesionales cada vez más preparados, sin duda, han podido influir. Pero con el inicio de la formación universitaria, la producción científica ha sido también muy fructífera en España, lo que demuestran los grupos y proyectos de investigación en las distintas universidades, los congresos y la cantidad de publicaciones o tesis doctorales. Por otro lado, España ha experimentado grandes cambios políticos y sociales en el último siglo que también pueden haber influido en la manera de traducir. Venuti afirma que las traducciones son "profoundly linked to their historical moment" (2004: 34) mientras que Hermans declara que son "socially and ideologically conditioned" (2007: 79). Con esta base, el proyecto de investigación «Estudios de interacción textual y cultural: las retraducciones» financiado por la Universidad Pontificia Comillas de Madrid pretende ubicar obras literarias canónicas en inglés, francés, alemán e italiano que se hayan traducido varias veces al español para determinar la interrelación que puede haber entre el contexto sociohistórico y la traducción en cada momento. Para ello, se está creando un corpus clasificado con datos tanto cuantitativos (número, fechas, editoriales, etc.) como cualitativos (contexto sociohistórico, relaciones socioculturales, procedimientos traductológicos, canon literario y traductor, etc.) sobre las retraducciones encontradas. En mi ponencia se dará un avance de los resultados obtenidos hasta este momento y se comentarán ejemplos de varias traducciones de la misma obra en el curso del tiempo.

Susanne M. Cadera es actualmente Directora del Departamento de Traducción e Interpretación en la Universidad Pontificia Comillas, Madrid (España). Imparte docencia de lengua, cultura y literatura alemanas y cursos de doctorado en el ámbito de la teoría de traducción literaria. Sus principales áreas de investigación se desarrollan en temas como la traducción de la oralidad ficticia (literaria), en la retraducción de obras literarias y en la traducción de aspectos culturales. Publicaciones en estos ámbitos son por ejemplo los capítulos: "Translating Fictive Dialogue in Novels" and "Representing Phonetic Features" de The Translation of Fictive Dialogue (2012) o la edición del libro Voices of Suspense and Their Translation in Thrillers (2014), editado con A. Pavič. 